\title{
Research on the Path of Digital Inclusive Finance's Influence on Industrial Structure Upgrade
}

\author{
Yijing $\mathrm{Li}^{1}$, Kairong $\mathrm{Ma}^{2 *}$
}

\author{
${ }^{1}$ Wuhan University of Technology \\ ${ }^{2}$ Zhongnan University of Economics and Law \\ ${ }^{*}$ Corresponding author. Email: $1440162491 @$ qq.com \\ ABSTRACT
}

This article takes digital inclusive finance and industrial structure upgrading as the research object, using the Peking University digital inclusive finance Index and the data of 285 prefecture-level cities from 2011 to 2018 construct an intermediary effect model. The research results show that digital inclusive finance has significantly promoted the upgrading of our country's industrial structure. At the same time, digital inclusive finance can promote the upgrading of industrial structure through technological innovation, capital accumulation, productivity improvement, and consumer demand effects. Government departments and financial institutions need to increase investment in science and technology, promote the deep integration of digital technology and inclusive finance.

Keywords: Digital inclusive finance, Industrial structural upgrade, Mediation effect.

\section{INTRODUCTION}

In recent years, relying on digital technologies such as information, big data and cloud computing, China's digital economy has developed rapidly and has become a new engine for our country's economic development. As an important part of the digital economy, digital inclusive finance integrates innovative technology and the financial industry. By expanding the coverage of finance, reducing transaction costs and financial service costs, it effectively broadens the depth and breadth of the financial industry and its applications. As a new thinking and new perspective, digital inclusive finance in the new stage of China's transformation and upgrading deserves more attention and research. However, the development of digital inclusive finance is still in its infancy. The efficiency of inclusive finance has not really increased, and the development of digital finance urgently needs support from multiple sources for improvement. Financial factors and the upgrading of industrial structure have been widely concerned by a large number of economists.

At this stage, the economy of China is in a critical period of high-speed transition to high-quality. Industrial structure adjustment and technological innovation are the main features of the new economic normal. The "structural dividend" brought about by the upgrading of industrial structure is an important factor in promoting economic development. Promoting the transformation and upgrading of the industrial structure has become one of the main goals and tasks of economic and social development. As a result, technological innovation is insufficient and capital effects are difficult to achieve. This has caused a series of problems such as unreasonable industrial structure and mismatch between supply and demand of low-end products and high-end products.

Financial factors and the upgrading of industrial structure have been widely concerned by a large number of economists. Existing studies have shown that digital inclusive finance is an important factor in promoting the upgrading of industrial structure. The development of digital inclusive finance is not only an important way for financial development, but also a necessary condition for the upgrading of industrial structure and the realization of optimal economic growth. Digital inclusive finance services can significantly improve industrial agglomeration, reduce corporate financing costs, and improve the efficiency of credit resource allocation, thus forming an important channel that affects the upgrading of industrial structure.

In summary, traditional research integrated digital inclusive finance concerns and upgrading of industrial structure is still in the stage of shortage, and empirical test on the relationship between them still relatively weak. The marginal contributions of this article are as follows: first, use the China digital inclusive finance 
Index and the data of 285 prefecture-level cities from 2011 to 2018 to further study the relationship between digital inclusive finance and industrial structure upgrading. Second, further mining by selecting intermediary variables and analyze the mechanism through which digital inclusive finance is used to optimize the industrial structure, with a view to enriching the literature on the factors of industrial structure optimization from the level of digital inclusive finance to a certain extent.

\section{LITERATURE REVIEW THEORETICAL ANALYSIS}

AND

\subsection{The relationship between digital inclusive finance and industrial structure upgrading}

The relationship between finance and the upgrading of industrial structure has attracted the attention of a large number of scholars. Studies have verified that financial factors are an important factor in promoting the upgrading of industrial structure. The improvement of financial structure is not only an important way for financial development, but also a necessary condition for upgrading the industrial structure and achieving optimal economic growth[1]. To successfully achieve the goals of industrial upgrading and economic growth, it is necessary to establish a multi-level financial market, provide high-quality innovative enterprises with suitable high-quality financial services, and enable continuous support and promotion of innovative activities in the real economy. Continuous upgrading of digital inclusive finance services through its low-cost and low-threshold advantages can significantly improve industrial agglomeration, reduce corporate financing costs, and improve the efficiency of credit resource allocation, thus forming an important channel that affects the upgrading of industrial structure[2].

Therefore, this article proposes hypothesis one:

H1: Digital inclusive finance can promote the upgrading of industrial structure.

\subsection{Impact mechanism of digital inclusive finance on the upgrading of industrial structure}

\subsubsection{Technological innovation effect}

Financial development is the direct cause of technological innovation and has a positive effect on promoting technological progress[3]. Digital inclusive finance, as a product of the collaborative innovation of technology and finance, can directly produce technology spillover effects through its advanced technology and innovation advantages. It can directly promote technological innovation and progress in the industry through technology spillover effects, competitive effects, and industry optimization effects. The financial system can promote industrial technological progress by stimulating entrepreneurship and technological innovation, and then influence the transformation and upgrading of industrial structure through the supply endogenous driving force of structural transformation. Digital inclusive finance that integrates scientific and technological elements has improved the development of technology, data and other element markets, prospered technology market transactions and enhanced data market development, provided better information services, platform transactions, which for both technology data supply, demand parties and service guarantee[4].Under the development of digital inclusive finance, small and micro enterprises have the necessary funds for technological reform and R\&D innovation, which in turn promotes productivity improvement.

Therefore, this article proposes hypothesis two:

H2: Digital inclusive finance promotes industrial structure upgrading through technological innovation.

\subsubsection{Capital accumulation effect}

Digital inclusive finance broadens the breadth of financial applications, promotes diversified development of financial services. To a large extent promotes the effective conversion of capital accumulation to investment, and supports the optimization and upgrading of economic structure through the resource allocation function of finance. The configuration between the two has promoted the upgrading of the industrial structure[5].The development of digital inclusive finance has promoted financial institutions to complete capital formation and primitive accumulation by absorbing deposits, and adjust the amount of investment in the optimal capital required by enterprises for production, thereby strengthening the function of resource allocation and optimizing credit funds in the industry. As an important embodiment of digital finance, Digital inclusive finance has reduced the rationing of credit to a certain extent and promoted the rational allocation of financial capital. Digital inclusive finance can provide personalized financial products and digital financial services by accurately matching the user groups of various industrial chains, thereby further promoting the rational and efficient allocation of financial resources and promoting the upgrading of the industrial structure[6].As a result, the capital accumulation and investment growth brought about by digital inclusive finance can promote technological innovation in the industry, promote technological progress, capital deepening, and expansion of capital accumulation, thereby effectively promoting the upgrading of the industrial structure. 
Therefore, this paper proposes hypothesis three:

H3: Digital inclusive finance promotes industrial structure upgrading through capital accumulation.

\subsubsection{Productivity improvement effect}

To a certain extent, the national economic growth rate is closely related to the rate of labor productivity growth[7].On the one hand, from the perspective of employment structure, under the influence of digital inclusive finance, labor productivity has increased. The employment of low-skilled labor is driven by the tertiary industry. The service industry has become an important driving force for the advanced development of the industry, leading to the tertiary industry. The relative output value is getting bigger and bigger, thus promoting the heightening of the industrial structure. On the other hand, from the perspective of technological structure, under the impetus of digital inclusive finance, the increase in labor productivity has promoted expansion of demand for highly skilled labor, and promoted transformation of labor-intensive traditional industries to technology-intensive industries. Accelerate the integration and development of technology updates and the technology industry. At the same time, digital inclusive finance meets the financing needs of small, medium and micro enterprises, forcing them to achieve technological advancement and innovation. As the main force of innovation and entrepreneurship, small, medium and micro enterprises can indirectly promote the upgrading of industrial structure through innovation and entrepreneurship[8].

Therefore, this paper proposes hypothesis four:

H4: Digital inclusive finance promotes industrial structure upgrading by increasing productivity.

\subsubsection{Consumer demand effect}

Financial capital plays a role in promoting the coordinated development of the market and enterprises. There is a benign interactive relationship. The rich and diversified financial products can stimulate the increase of consumer demand[9], the diversification of consumer demand will promote the transformation and upgrading of the industrial structure. The changes in consumer demand brought about by the development of the technology and financial industry can alleviate the "bottlenecks" of national production factors and "overcapacity" problems, while stimulating the development of other demanding product sectors, thereby achieving the goal of improving the domestic industrial structure. Changes in the structure of import and export commodities triggered by consumer demand will stimulate domestic enterprises to accelerate the pace of reform and innovation, and advanced development of the industrial structure while giving full play to the country's comparative advantages[10].
Therefore, this article proposes hypothesis five:

H5: Digital inclusive finance promotes industrial structure upgrading by increasing consumer demand.

According to the summary of the literature, there are relatively many documents studying the impact of the financial industry on the industrial structure, and there are still few studies on digital inclusive finance and industrial structure upgrading, and some documents only provide theoretical analysis of its mechanism of action. The path is not comprehensive yet. And this article attempts to further empirically test on the supplement of existing theories. With the advancement of China's digital inclusive finance development process, it is of great significance to explore the specific path through which digital inclusive finance affects the upgrading of the industrial structure. Therefore, relative to the existing literature, this article sets technological innovation, labor productivity, capital accumulation, and consumer demand as intermediary variables and incorporates it into the impact mechanism of digital inclusive finance on the upgrading of industrial structure for empirical testing, with a view to enriching the relevant path of the impact of China's industrial structure upgrading the literature, and its further discussion of the research results also provide references for finding industrial policies that are in line with our country's reality.

\section{INDEX SELECTION AND MODEL SETTING}

\subsection{Index selection}

\subsubsection{Explained variable: Industrial structural upgrade}

In order to fully and accurately reflect the research purpose of this article and the connotation of industrial structure upgrading, the following draws on the research of Min Xu and Yong Jiang (2015) and Wei Wang et al. (2015) to construct an industrial structure upgrading index to represent the level of industrial structure upgrading. The larger the index value, the higher the upgrading level of the industrial structure. The specific calculation method is: $I S=\sum_{\mathrm{i}=1}^{3} \mathrm{q}_{\mathrm{i}} \times \mathrm{i}$

In the above formula, IS represents the industrial structure upgrading index, and qi represents the proportion of the i-th industry's GDP. In order to prevent the occurrence of false regression, while not changing the objective authenticity of the regression results, the Ln ISI is obtained by natural logarithmic processing.

\subsubsection{Explanatory variables: digital inclusive finance}

This paper uses the China digital inclusive finance 
Index jointly compiled by Peking University Digital Finance Research Center and Ant Financial Group as the core explanatory variable.

\subsubsection{Mediating variable}

Technological Innovation: this article refers to the method of Qingtian $\mathrm{Wu}$ and Yingxiao $\mathrm{Zhu}$ (2021)[11]using the logarithmic value of the number of invention patents granted by provinces and cities. (2)Capital Asset: this article refers to the method of Jinmin Du et al. (2020)[12].(3)Labor productivity: This article refers to the method of Jianyong Fan (2006)[13] (4)Consumption demand: This article refers to the research method of Mao Yang (2006)[14].

\subsubsection{Control variable}

This section selects the regional economic development level (GDP), regional population density (POP), foreign direct investment (FDI), Government expenditure (GOV) as a control variable to examine.

\subsection{Model building}

Based on research hypothesis 1, in order to test whether the development of digital inclusive finance can play a positive role in the upgrading of industrial structure, this paper first sets the direct effect model as follows:

$$
\begin{gathered}
\text { ISI }=\beta_{10}+\beta_{11} \mathrm{DIF}_{\mathrm{it}}+\beta_{12} \operatorname{Ln}(\mathrm{GDP})_{\mathrm{it}}+ \\
\beta_{13} \operatorname{Ln}(\mathrm{POP})_{\mathrm{it}}+\beta_{14} \operatorname{Ln}(\mathrm{FDI})_{\mathrm{it}}+\beta_{15} \operatorname{Ln}(\mathrm{GOV})_{\mathrm{it}}+\varepsilon_{1 \mathrm{it}}
\end{gathered}
$$

According to the analysis of the above chapters, this section selects technological innovation, capital, labor productivity, and consumer demand as the intermediary variables for studying the development of digital inclusive finance on the upgrading of industrial structure, and refers to the intermediary effect model of Zhonglin Wen and Baojuan Ye (2014) for testing. The mediating effect model is shown below:

ISI $=\beta_{20}+\beta_{21}$ DFI $_{\text {it }}+\beta_{22} \operatorname{Ln}(\mathrm{GDP})_{\mathrm{it}}+$ $\beta_{23} \operatorname{Ln}(\mathrm{POP})_{\mathrm{it}}+\beta_{24} \operatorname{Ln}(\mathrm{FDI})_{\mathrm{it}}+\beta_{25} \operatorname{Ln}(\mathrm{GOV})_{\mathrm{it}}+\varepsilon_{2 \mathrm{it}}$

Mediator $_{\text {it }}=\beta_{30}+\beta_{31}$ DIF $_{\text {it }}+\beta_{32} \operatorname{Ln}(G D P)_{\text {it }}+$ $\beta_{33} \operatorname{Ln}(\mathrm{POP})_{\mathrm{it}}+\beta_{34} \operatorname{Ln}(\mathrm{FDI})_{\mathrm{it}}+\beta_{35} \operatorname{Ln}(\mathrm{GOV})_{\mathrm{it}}+\varepsilon_{3 \mathrm{it}}$

$$
\begin{aligned}
& \text { ISI }_{i t}=\beta_{40}+\beta_{41} \text { DIF }_{\text {it }}+\beta_{43} \text { Mediator }_{\text {it }}+ \\
& \beta_{44} \operatorname{Ln}(\mathrm{GDP})_{\mathrm{it}}+\beta_{44} \operatorname{Ln}(\mathrm{POP})_{\mathrm{it}}+\beta_{45} \operatorname{Ln}(\mathrm{FDI})_{\mathrm{it}}+ \\
& \beta_{46} \operatorname{Ln}(\mathrm{GOV})_{\mathrm{it}}+\varepsilon_{4 \mathrm{it}}
\end{aligned}
$$

Among them, Mediator is an intermediate variable, including technological innovation, capital asset, labor productivity, and consumption demand.

\subsection{Data sources}

The data come from the Peking University digital inclusive finance Index Database and the websites of the provincial and municipal statistical bureaus. Panel data of 285 prefecture-level cities in our country from 2016

\begin{tabular}{|c|c|c|c|c|}
\hline & Variable name & & Data used & Data sources \\
\hline $\begin{array}{l}\text { Explained } \\
\text { variable }\end{array}$ & Industrial Structural Upgrade & ISU & $\begin{array}{l}\text { Primary Industry GDP } \\
\text { Secondary Industry GDP } \\
\text { Tertiary Industry GDP }\end{array}$ & $\begin{array}{l}\text { Provincial Database } \\
\text { Provincial Database } \\
\text { Provincial Database }\end{array}$ \\
\hline $\begin{array}{l}\text { Explanatory } \\
\text { variables }\end{array}$ & Digital Inclusive Finance & DIF & Digital Inclusive Finance Index & $\begin{array}{l}\text { Peking } \quad \text { University } \\
\text { Digital } \quad \text { Financial } \\
\text { Research Center }\end{array}$ \\
\hline \multirow{4}{*}{$\begin{array}{l}\text { Mediating } \\
\text { Variable }\end{array}$} & Technological innovation & Innov & $\begin{array}{l}\text { Logarithm of the number of patents } \\
\text { granted for invention }\end{array}$ & Provincial Database \\
\hline & Capital Asset & Asset & $\begin{array}{l}\text { Social investment in fixed assets per } \\
\text { capital }\end{array}$ & Provincial Database \\
\hline & Labor Productivity & Labor & $\begin{array}{l}\text { Non-agricultural } \\
\text { GDP/Non-agricultural employment }\end{array}$ & Provincial Database \\
\hline & Consumption Demand & Consum & Total social retail consumer goods & Provincial Database \\
\hline \multirow{3}{*}{$\begin{array}{l}\text { Control } \\
\text { variable }\end{array}$} & Economic Development Lever & GDP & Regional GDP & Provincial Database \\
\hline & Regional Population Density & POP & $\begin{array}{l}\text { Regional population density } \\
(\text { person } / \mathrm{km} 2)\end{array}$ & Provincial Database \\
\hline & Actual Foreign Investment & FDI & Actual foreign investment & Provincial Database \\
\hline
\end{tabular}
to 2019 are selected for analysis, and the missing data is filled by interpolation. The specific situation is shown in Table 1 below:

Table 1 Research variable system 


Local Government Expenditure GOV Local general public budget Provincial Database

\section{Empirical analysis}

\subsection{Variable descriptive statistics}

Table 2 Descriptive statistics of the main variables

\begin{tabular}{|c|c|c|c|c|c|c|c|}
\hline & Variable name & & Observations & Average & $\begin{array}{l}\text { Standard } \\
\text { deviation }\end{array}$ & Min & Max \\
\hline Explained variable & $\begin{array}{l}\text { Industrial } \\
\text { Upgrade }\end{array}$ & $\operatorname{Ln}(\mathrm{ISI})$ & 2346 & 2.36 & 0.03 & 2.04 & 2.45 \\
\hline $\begin{array}{l}\text { Explanatory } \\
\text { variables }\end{array}$ & Digital Inclusive Finance & DIF & 2346 & 155 & 61.89 & 17.0 & 302 \\
\hline \multirow{4}{*}{ Mediating Variable } & Technological innovation & $\begin{array}{l}\text { Ln(innova } \\
\text { tion) }\end{array}$ & 2346 & 3.20 & 0.72 & 0.00 & 5.22 \\
\hline & Capital Asset & $\operatorname{Ln}($ asset) & 2346 & 6.61 & 0.65 & 4.86 & 8.56 \\
\hline & Labor Productivity & $\operatorname{Ln}$ (labor) & 2346 & 16.86 & 10.64 & 0.00 & 95.2 \\
\hline & Consumption Demand & $\begin{array}{l}\operatorname{Ln}(\text { consu } \\
\text { mption })\end{array}$ & 2346 & 6.46 & 0.60 & 4.94 & 8.36 \\
\hline \multirow{4}{*}{ Control variable } & $\begin{array}{l}\text { The level of Economic } \\
\text { Development }\end{array}$ & $\operatorname{Ln}(g d p)$ & 2346 & 7.13 & 0.43 & 5.54 & 8.51 \\
\hline & $\begin{array}{l}\text { Regional Population } \\
\text { Density }\end{array}$ & $\operatorname{Ln}(p o p)$ & 2346 & 2.48 & 0.40 & 0.71 & 3.42 \\
\hline & Actual Foreign Investment & $\operatorname{Ln}(f d i)$ & 2346 & 4.41 & 0.77 & 0.48 & 6.49 \\
\hline & $\begin{array}{ll}\text { Local } & \text { Government } \\
\text { Expenditure } & \\
\end{array}$ & Ln(gov) & 2346 & 6.00 & 0.49 & 4.00 & 7.85 \\
\hline
\end{tabular}

\subsection{Empirical results and analysis}

Based on the above theoretical analysis and research design, this section empirically analyzes the impact of the development of digital inclusive finance on the industrial structure. The fixed effects model used here controls both time and individual factors. Table 3 reports the regression results of formula (1).

Table 3 Direct effects model regression results

\begin{tabular}{|c|c|c|c|c|c|}
\hline variable & $\overline{(1) I S I}$ & $\overline{(2) I S I}$ & $\overline{(3) I S I}$ & (4)ISI & $\overline{(5) I S I}$ \\
\hline DIF & $\begin{array}{l}0.0539 * * * \\
(0.0027)\end{array}$ & $\begin{array}{l}0.0364 * * * \\
(0.0025)\end{array}$ & $\begin{array}{l}0.0295 * * * \\
(0.0032)\end{array}$ & $\begin{array}{l}0.0280 * * * \\
(0.0033)\end{array}$ & $\begin{array}{l}0.0185 * * * \\
(0.0032)\end{array}$ \\
\hline GDP & & $\begin{array}{l}0.0295 * * * \\
(0.0014)\end{array}$ & $\begin{array}{l}0.0299 * * * \\
(0.0020)\end{array}$ & $\begin{array}{l}0.0269 * * * \\
(0.0028)\end{array}$ & $\begin{array}{l}0.0205 * * * \\
(0.0045)\end{array}$ \\
\hline POP & & & $\begin{array}{l}0.0026 \\
(0.0019)\end{array}$ & $\begin{array}{l}0.0023 \\
(0.0019)\end{array}$ & $\begin{array}{l}0.0038^{*} \\
(0.0018)\end{array}$ \\
\hline FDI & & & & $\begin{array}{l}0.0051 * * * \\
(0.0014)\end{array}$ & $\begin{array}{l}-0.0004 \\
(0.0014)\end{array}$ \\
\hline GOV & & & & & $\begin{array}{l}0.0522 * * * \\
(0.0041)\end{array}$ \\
\hline Individual effect & YES & YES & YES & YES & YES \\
\hline Time effect & YES & YES & YES & YES & YES \\
\hline Constant & $\begin{array}{l}2.2409 * * * \\
(0.0052)\end{array}$ & $\begin{array}{l}2.0659 * * * \\
(0.0099)\end{array}$ & $\begin{array}{l}2.0697 * * * \\
(0.0121)\end{array}$ & $\begin{array}{l}2.0723 * * * \\
(0.0151)\end{array}$ & $\begin{array}{l}2.137 * * * \\
(0.0152)\end{array}$ \\
\hline
\end{tabular}




\begin{tabular}{llllll}
\hline Obs & 2346 & 2346 & 2346 & 2346 & 2346 \\
R-squared & 0.1694 & 0.3153 & 0.2937 & 0.3215 & 0.3953 \\
\hline
\end{tabular}

Note: Standard errors are shown in parentheses; $* * *$, and $* * *$ indicate significant at the $10 \%, 5 \%$, and $1 \%$ levels, respectively.

From the empirical results of the stepwise regression in Table 3, there is a positive correlation between digital inclusive finance and industrial structure upgrading and both are significant at the $1 \%$ level, which verifies the research hypothesis $\mathrm{H} 1$ proposed in this paper. The following uses technological innovation, capital, labor productivity, and consumer demand as intermediary variables to further explore the impact of the development of the digital economy on the industrial structure. The results of the publicity (2) regression are shown in Table 4 below.

Table 4 Regression results of the mediation effect model

\begin{tabular}{|c|c|c|c|c|c|}
\hline Variable & Innovation & Asset & Labor & Consumption & ISI \\
\hline \multirow[t]{2}{*}{ DIF } & $0.5697 * * *$ & $0.5106^{* * *}$ & 0.0281 & $0.2866^{* * *}$ & $0.0109 * * *$ \\
\hline & $(0.0461)$ & $(0.0973)$ & $(0.0226)$ & $(0.0897)$ & $(0.0037)$ \\
\hline \multirow[t]{2}{*}{ Innovation } & & & & & $0.0101 * * *$ \\
\hline & & & & & $(0.0020)$ \\
\hline \multirow[t]{2}{*}{ Asset } & & & & & -0.0016 \\
\hline & & & & & $(0.0255)$ \\
\hline \multirow[t]{2}{*}{ Labor } & & & & & $0.0218 * * *$ \\
\hline & & & & & $(0.0042)$ \\
\hline \multirow[t]{2}{*}{ Consumption } & & & & & 0.0027 \\
\hline & & & & & $(0.0027)$ \\
\hline \multirow[t]{2}{*}{ GDP } & $0.7090^{* * *}$ & 0.1357 & $0.3002 * * *$ & $0.2269 *$ & $-0.0302 * * *$ \\
\hline & $(0.0776)$ & $(0.0384)$ & $(0.0351)$ & $(0.1247)$ & $(0.0057)$ \\
\hline \multirow[t]{2}{*}{ POP } & $0.3875^{* * *}$ & 0.0342 & $-0.0825 * * *$ & $0.1012 * *$ & 0.0012 \\
\hline & $(0.0361)$ & $(0.0546)$ & $(0.0165)$ & $(0.0503)$ & $(0.0022)$ \\
\hline \multirow[t]{2}{*}{ FDI } & $0.0942 * * *$ & -.0415 & -0.0030 & -.0501 & -0.0016 \\
\hline & $(0.0235)$ & $(0.0402)$ & $(0.0102)$ & $(0.0372)$ & $(0.0014)$ \\
\hline \multirow[t]{2}{*}{ GOV } & $0.3501 * * *$ & $-0.2590 * *$ & $-.0887 * * *$ & $0.2788^{* * *}$ & $0.0477 * * *$ \\
\hline & $(0.0734)$ & $(0.1206)$ & $(0.0328)$ & $(0.1110)$ & $(0.0043)$ \\
\hline Time effect & YES & YES & YES & YES & YES \\
\hline Individual effect & YES & YES & YES & YES & YES \\
\hline \multirow[t]{2}{*}{ Constant } & $6.5704 * * *$ & $4.9552 * * *$ & $0.2150 * *$ & $5.0415^{* * *}$ & $2.1935^{* * *}$ \\
\hline & $(0.232)$ & 0.4559 & $(0.1120)$ & $(0.4198)$ & $(0.0215)$ \\
\hline Obs & 2346 & 2346 & 2346 & 2346 & 2346 \\
\hline $\mathrm{R} 2$ & 0.7748 & 0.0257 & 0.1718 & 0.0157 & 0.4007 \\
\hline
\end{tabular}

The above model tested the influence of the accumulation, labor productivity and consumer demand development of digital inclusive finance on the intermediary variables and the upgrading of industrial structure. The regression results showed that the development of digital inclusive finance had a certain promotion effect on technological innovation, capital

But does the development of digital inclusive finance affect the upgrading of industrial structure through intermediary variables? Therefore, this section uses the Sobel test to test the mediation effect:

Table 5 Mediating effect test

\begin{tabular}{llllll} 
& Estimated coefficient & Bootstrap Standard error & $\mathrm{Z}$ & \multicolumn{2}{l}{$95 \%$ Confidence interval } \\
\hline Innovation & $0.0340^{* * *}$ & 0.0029 & 11.56 & 0.0283 & 0.0396 \\
\hline Asset & $0.0525 * *$ & 0.0027 & 19.69 & 0.0471 & 0.0578 \\
\hline Labor & $0.0493 * *$ & 0.0024 & 20.52 & 0.0446 & 0.0541 \\
\hline Consumption & $0.0525 * * *$ & 0.0025 & 20.54 & 0.0475 & 0.0575 \\
\hline
\end{tabular}

According to the above table, the $95 \%$ confidence interval of technological innovation, capital accumulation, labor productivity, and consumption demand does not include 0 . The $\mathrm{P}$ value corresponding 
to the Sobel test is less than 0.01 , and the intermediary variables are significant at the $1 \%$ level. Therefore, The mediation effect is significant.

\subsection{Robustness test}

In order to further test the robustness of the above conclusions, this article attempts to re-examine the impact of industrial intelligence on the quality of economic growth in two ways, as a robustness test: (1) Eliminate macro variables. This article controls the micro variables as well as the macro variables. (2) Replace the core explanatory variables. This article also draws on this method and re-estimates it. After the robustness test of the two methods, the regression results obtained are basically consistent with the above estimation results, indicating that the research conclusions of this paper have a certain degree of robustness.

\section{CONCLUSIONS AND POLICY}

\section{RECOMMENDATIONS}

The research results show that: first, digital inclusive finance has promoted the upgrading of our country's industrial structure, and has a significant effect on promoting the advancement of country's industrial structure; second, digital inclusive finance can be achieved through technological innovation, capital accumulation, labor productivity improvement and consumer demand, etc. Changes in factors have strongly promoted the upgrading of the industrial structure.

Based on the research results, this article puts forward the following policy recommendations:

First, strengthen the promotion of digital inclusive finance and deepen the structural reform of the financial supply side. Accelerate the broadening of the service boundaries of technology and finance, and promote the information advantages, cost advantages, risk control advantages and long tail effects of digital inclusiveness to benefit a wider consumer group.

Second, actively respond to the development strategy of technological innovation, increase investment in scientific research, and optimize the supporting role of technological innovation in the development of the financial industry.

Third, accelerate the transformation of the mode of economic growth from focusing on factor input to focusing on improving efficiency. Change the previous pursuit of total growth to quality growth, and lead the future industrial development strategy and path.

\section{ACKNOWLEDGMENT}

Fund source:Special Funds for Fundamental Research Expenses of Central Universities.

\section{REFERENCES}

[1] Fangzhi Fan, Lijun Zhang.Research on China's Regional Financial Structure Transformation and Industrial Structure Upgrade[J].Financial Research,2003(11):36-48.

[2] Dan Sheng, Yongjin Wang . Industry Agglomeration, Credit Resource Allocation Efficiency and Enterprise Financing Costs-Evidence from World Bank Survey Data and Chinese Industrial EnterpriseData[J].Managementworld,2013(06):8598.

[3]Miaomiao Li ,Hongjun Xiao ,Shuang Zhao .Research on the Relationship between Financial Development, Technological Innovation and Economic Growth——Based on China's Provincial and Municipal Panel Data[J].China Management

[4] Ceng Hou ,Beiwei Li .Did financial technology improve total factor productivity? Empirical evidence from Peking University's digital inclusive finance Index[J].Finance and Economics,2020(12):1-12.

[5] MIRIAM BRUHN, INESSA LOVE. The Real Impact of Improved Access to Finance: Evidence from Mexico. 2014, 69(3):1347-1376.

[6] Yiping Huang ,Zhuo Huang .The development of digital finance in China: present and future [J].Economics(Quarterly),2018,17(04):1489-1502.

[7] Fuhua Yuan . "Structural acceleration" and "structural deceleration" in the long-term growth process: an explanation[J].Economic Research,2012,47(03):127-140.

[8] Wenjin Tang ,Shuang Li ,Yunqing Tao . The development of digital inclusive finance and the upgrading of industrial structure: empirical evidence from 283 cities[J].Journal of Guangdong University of Finance and Economics,2019,34(06):35-49.

[9] Xiangyun Liu ,Wenyang Wu .The co-evolution mechanism and empirical test of technology finance and high-tech industry_- from Guangdong practice[J].Journal of Guangdong University of Finance and Economics,2018,33(03):20-32.

[10] Haiya Cai , Yingzhi Xu . Has the opening up of trade affected the upgrading of China's industrial structure?[J].Journal of Quantitative Economics and Technical Economics,2017,34(10):3-22. 
[11] Qingtian Wu,Yingxiao Zhu .Research on the Impact of digital inclusive finance on Enterprise Technological Innovation__Phase Mechanism Identification and Heterogeneity Analysis[J].Industrial Technology \& Economy,2021,40(03):143-151.

[12] Jinmin Du ,Shiwei Wei, Wenyang Wu .Does digital inclusive finance promote the optimization of industrial structure?[J].Comparison of Economic and Social Systems,2020(06):38-49.

[13] Jianyong Fan .Industrial Agglomeration and Regional Labor Productivity Differences[J].Economic Research,2006(11):72-81.

[14] Mao Yang .An Empirical Analysis of the Effects of Chinese Consumer Confidence and Consumer Demand[J]. Economic Survey, 2006(01):21-23. 